\title{
Nonspecific Lipid-Transfer Protein Genes Expression in Grape (Vitis sp.) Cells in Response to Fungal Elicitor Treatments
}

\author{
Eric Gomès, ${ }^{1}$ Emeric Sagot, ${ }^{1}$ Cécile Gaillard, ${ }^{1}$ Laurent Laquitaine, ${ }^{1}$ Benoit Poinssot, ${ }^{2}$ Yves-Henri \\ Sanejouand, ${ }^{3}$ Serge Delrot, ${ }^{1}$ and Pierre Coutos-Thévenot ${ }^{1}$ \\ ${ }^{1}$ Laboratoire de Physiologie et Biochimie Végétale, CNRS UMR 6161, Université de Poitiers, 40 avenue du Recteur \\ Pineau, 86022 Poitiers, France; ' 2 Laboratoire de Biochimie, Biologie Cellulaire et Ecologie des Interactions Plantes \\ MicroOrganismes, INRA UMR 1047, 17 rue Sully, 21034 Dijon, France; ${ }^{3}$ Centre de Recherche Paul Pascal, Avenue Albert \\ Schweitzer, 33600 Pessac, France.
}

Submitted 25 September 2002. Accepted 2 January 2003.

\begin{abstract}
Nonspecific lipid transfer proteins (nsLTPs) are small, basic cystein-rich proteins believed to be involved in plant defense mechanisms. Three cDNAs coding nsLTPs from grape (Vitis vinifera sp.) were cloned by reverse-transcriptase-polymerase chain reaction (RT-PCR) and PCR. The expression of nsLTP genes was investigated in 41Brootstock grape cell suspension, in response to various defense-related signal molecules. Ergosterol (a fungispecific sterol) and a proteinaceous elicitor purified from Botrytis cinerea strongly and rapidly induced the accumulation of nsLTP mRNAs. Jasmonic acid, cholesterol, and sitosterol also promoted nsLTPs mRNA accumulation, although to a lesser extent, whereas salicylic acid had no effect. High performance liquid chromatography analysis indicated that the amounts of three LTP isoforms (previously named P1, P2, and P4) were increased by ergosterol. None of the four isoforms displayed any significant antifungal properties, with the exception of the $\mathbf{P 4}$ isoform, which reduced Botrytis mycelium growth in vitro, but only in calcium-free medium. The results are discussed in the context of plant-pathogen interactions.
\end{abstract}

Additional keywords: Botrytis cinerea, ergosterol, gene expression, plant defense.

Plant nonspecific lipid-transfer proteins (nsLTPs) are small (91 to 95 residues), basic polypeptides that were first characterized in potato in the mid-1970s (Kader 1975). They share several structural features, the most striking being eight strictly conserved cystein residues engaged in four disulfide bridges (Kader 1996; Yamada 1992). Despite efforts of numerous research groups, the role of these proteins is still a matter of debate. Based on experimental results, several hypothesis have been suggested. First, the in vitro lipid transfer capacity shown by Kader (1975) suggested that these proteins were involved in the intracellular traffic of phospholipids. However, the extracellular location of the protein and the fact that all the sequences known to date exhibit a secretion signal in the $\mathrm{N}$ terminal part of the peptide seem to rule out such a role for nsLTPs. These proteins are largely secreted during somatic embryogenesis of grape and carrot cell (Coutos-Thévenot et al.

Corresponding author: E. Gomès; E-mail: eric.gomes@univ-poitiers.fr 1992a, 1993; Fleming et al. 1992) and might be involved in plant development mechanisms. For these reasons, and based on the binding properties of fatty acid derivatives, Sterk and associates (1991) and Meijer and associates (1993) suggested that nsLTPs may be involved in the transport of cutin monomers during cuticle layer formation. However, this hypothesis has not yet been validated. More recently, several results suggested a role for nsLTPs in plant defense mechanisms. Indeed, different $10-\mathrm{kDa}$ basic proteins sharing homology with plant nsLTPs are induced during plant microorganism interactions (Blilou et al. 2000). Moreover, some of them are active against several pathogens with various degrees of specificity (Cammue et al. 1995; Carvalho et al. 2001; Kristensen et al. 2000; Molina et al. 1993). Expression of a barley nsLTP in transgenic tobacco and Arabidopsis spp. enhances tolerance to bacterial pathogens (Molina and Garcia-Olmedo 1997). However, the antimicrobial activity of the nsLTP does not seem to be related to their lipid transfer capacity (Cammue et al. 1995; Regente and De la Canal 2000).

Most of the nsLTPs described in literature were extracted from seed (Douady et al. 1985; Guerbette et al. 1999; Regente and De la Canal 2000), herbaceous plants (Kader et al. 1984; Kristensen et al. 2000; Molina et al. 1993), or beer (Jégou et al. 2000) by harsh treatments followed by chromatographic purification under drastic conditions. The 41B embryogenic grape cell suspensions, in which $30 \%$ of the extracellular proteins are nsLTPs when an auxin-free medium is used, provide an interesting alternative to obtain nsLTPs under much milder conditions (Coutos-Thévenot et al. 1992a, 1993). In this model system, the nsLTPs are purified to homogeneity by cation exchange chromatography followed by hydrophobic interaction chromatography. This allows the purification and characterization of four isoforms (named P1, P2, P3, and P4) of auxin down-regulated nsLTPs characterized by their amino acid sequence, maize and carrot antibody detection, and in vitro lipid transfer activity. Grape suspension cells are convenient for establishing structure-function relationships in the nsLTPs family and for studying the expression of nsLTP in response to various inducers. The nsLTPs are encoded by a multigenic family (Arondel et al. 2000; Kader 1997); therefore, different isoforms may correspond to different functions. It is, therefore, relevant to find out whether some isoforms are involved in grape defense reactions. The present article describes the cloning of several cDNAs encoding grape nsLTPs, and the accumulation of the corresponding mRNAs in the $41 \mathrm{~B}$ cells after treatment with signal molecules known to induce defense reactions in plants. 


\section{RESULTS}

Cloning grape LTP cDNAs.

To obtain nsLTP cDNAs, two strategies were developed which allowed the isolation of three full-length clones. First, alignment of 47 LTPs sequences at the amino acid level led to the identification of two conserved regions, which were used to design degenerate primers (forward primer: YTI GGI TAY YTI AAR AAY GG; reverse primer: RTT IAC ICC RCA IKY IBH NGG). Using this pair of primers, reverse transcriptase-polymerase chain reaction (RT-PCR) run on mRNA extracted from auxin-depleted suspension cell cultures generated a 193-bp fragment. This fragment was subcloned in the pGEM-T easy vector and sequenced. Database interrogation showed that the sequence obtained was highly homologous to the central part of LTPs cDNAs. The $5^{\prime}$ and $3^{\prime}$ missing ends of the 41B rootstock LTP cDNA were obtained by rapid amplification of cDNA ends (RACE)-PCR. The full-length cDNA was amplified by PCR with primers, including the start and the stop codons. The deduced amino acid sequence exhibited typical signatures of plant nsLTPs, including the strictly conserved cysteine residues, at positions $31,41,57,58,78,80,104$, and 118 (Fig. 1). In addition, amino acids 28 to 65 were identical to the $37 \mathrm{~N}$-terminal residues of the P1 (accession \# P80275) isoform characterized previously (Coutos-Thévenot et al. 1993).

Second, a primer was defined at the $5^{\prime}$ end of the 193-bp fragment, and PCR was performed on a $\lambda$ ZapII grape (cv. Pinot noir) cDNA library (Fillion et al. 1999) using the phageresident T7 primer sequence. A 299-bp fragment containing the

\begin{tabular}{rrrr}
\hline 10 & 10 & 30 & 40 \\
\hline
\end{tabular}

\begin{tabular}{|c|c|}
\hline 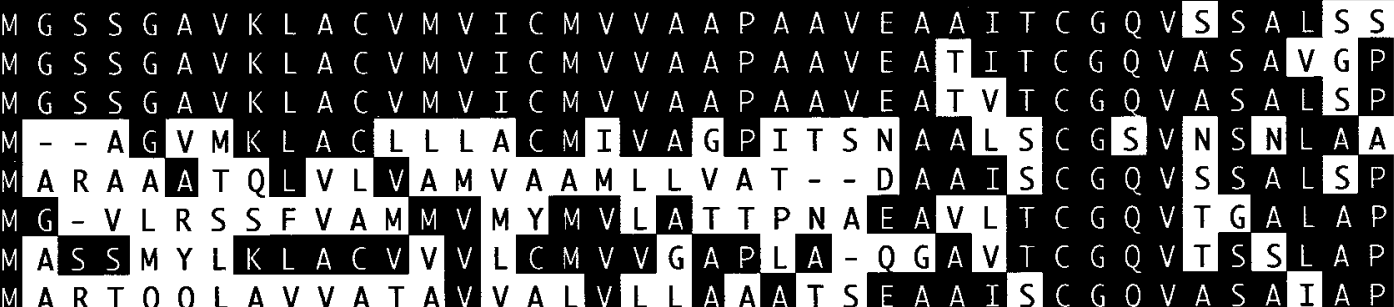 & $\begin{array}{l}\text { Pinot Noir } 1 \\
\text { Pinot Noir } 2 \\
\text { Arabidopsis } \\
\text { Barley } \\
\text { Carrot } \\
\text { Cotton } \\
\text { Maize }\end{array}$ \\
\hline
\end{tabular}

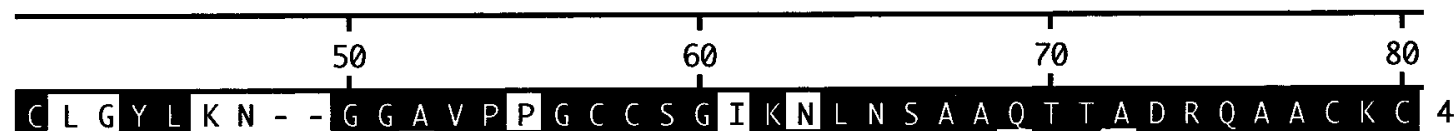

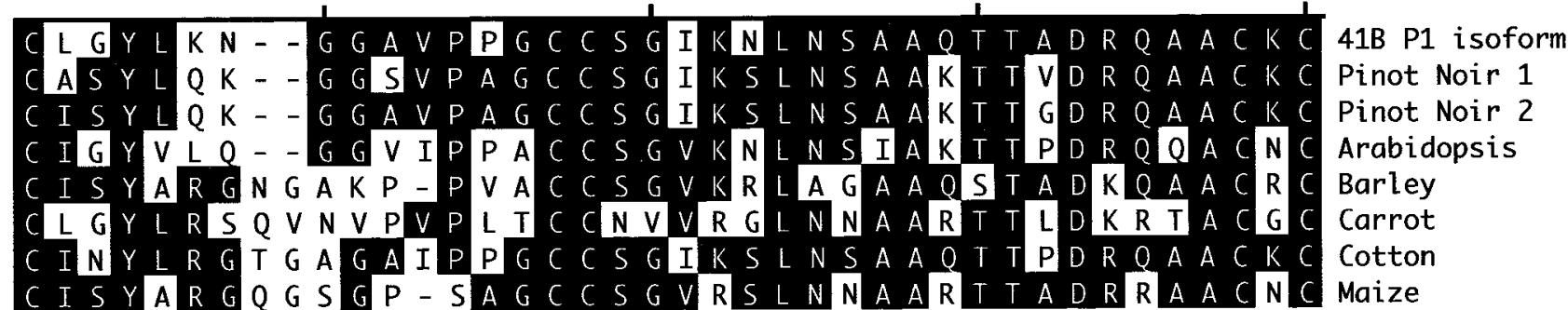

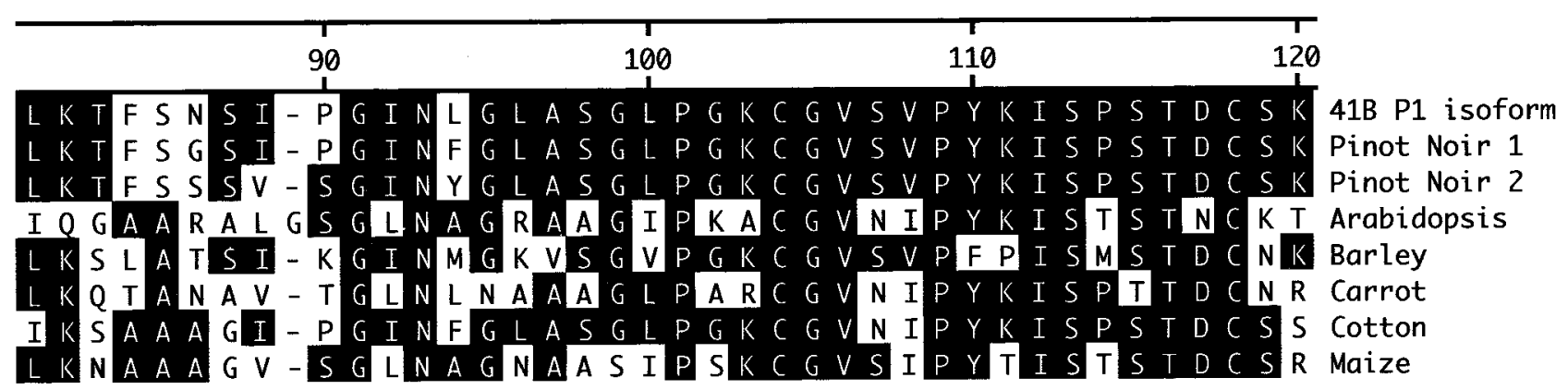

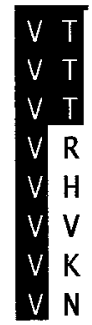

41B P1 isoform Pinot Noir 1

Pinot Noir 2

Arabidopsis

Barley

Carrot

Cotton

Maize

Fig. 1. Sequence alignment of different nonspecific lipid transfer proteins (nsLTPs). Grapevine sequences of P1 isoform cloned from 41B rootstock were compared with nsLTPs from Pinot Noir, Arabidopsis spp., barley, carrot, cotton, and maize. Black-boxed residues indicate conserved amino acids. Dashes indicate gaps. Alignments were performed with the clustal V program of the DNA Star package. Grapevine sequences have deposited in the GenBank database (accession numbers: 41B, AF465408; Pinot noir 1, AF467945; Pinot noir 2, AF467946). 
stop codon was obtained. A reverse primer including the $3^{\prime}$ end of the open reading frame was used in conjunction with the T3 primer to amplify the full-length cDNA. After subcloning and sequencing, it appeared that two different Pinot noir LTPs cDNA were amplified. One sequence matched with the 41B P4 isoform (accession \#P80274) previously described (CoutosThevenot et al. 1993), and the other one was more closely related to P1 (Fig. 1).

\section{Induction of nsLTP gene expression}

in $41 B$ cell suspension cultures.

Potential inducers of LTPs expression in grape are unknown. In this context, the effects of several compounds related to defense mechanisms on LTP expression were investigated. Northern blot analysis (Fig. 2A, upper panel) were performed with RNA extracted from cells treated by jasmonic acid (JA), salicylic acid (SA), or different sterols, including ergosterol, which is fungus specific and is an active elicitor of defense reactions (Granado et al. 1995). All of these chemicals were dissolved in ethanol; therefore, an identical volume of ethanol was added in the control experiment. Using the entire 41B LTP cDNA as a probe, the strongest hybridization signals were de- tected in ergosterol treatments. A faint signal also appeared in the control treated cells, indicating that expression was not induced by ethanol. SA treatment did not induce a significant and reproducible increase of LTP transcripts compared to the ethanol control. However, the amount of LTP transcripts was slightly but consistently increased by JA, sitosterol, and cholesterol.

To confirm induction of LTPs expression by fungal elicitors, 41B grape cells were treated by a water-dialyzed culture filtrate of Botrytis cinerea, a well-known grape pathogen. This treatment strongly increased the amount of LTP transcripts compared with the water control (Fig. 2B, upper panel). The active molecule in this filtrate was further purified by exclusion chromatography and identified as a protein fraction. Final purification, biochemical characterization, and identification of the active protein are under way (B. Poinssot and A. Pugin, unpublished data).

The most potent inducers were chosen to characterize more precisely the kinetics of expression (Fig. 3). LTPs mRNA levels started to increase $5 \mathrm{~h}$ after the addition of either ergosterol or the purified proteinaceous elicitor of Botrytis spp., and continued accumulating throughout the 30 -h duration of the ex-
A
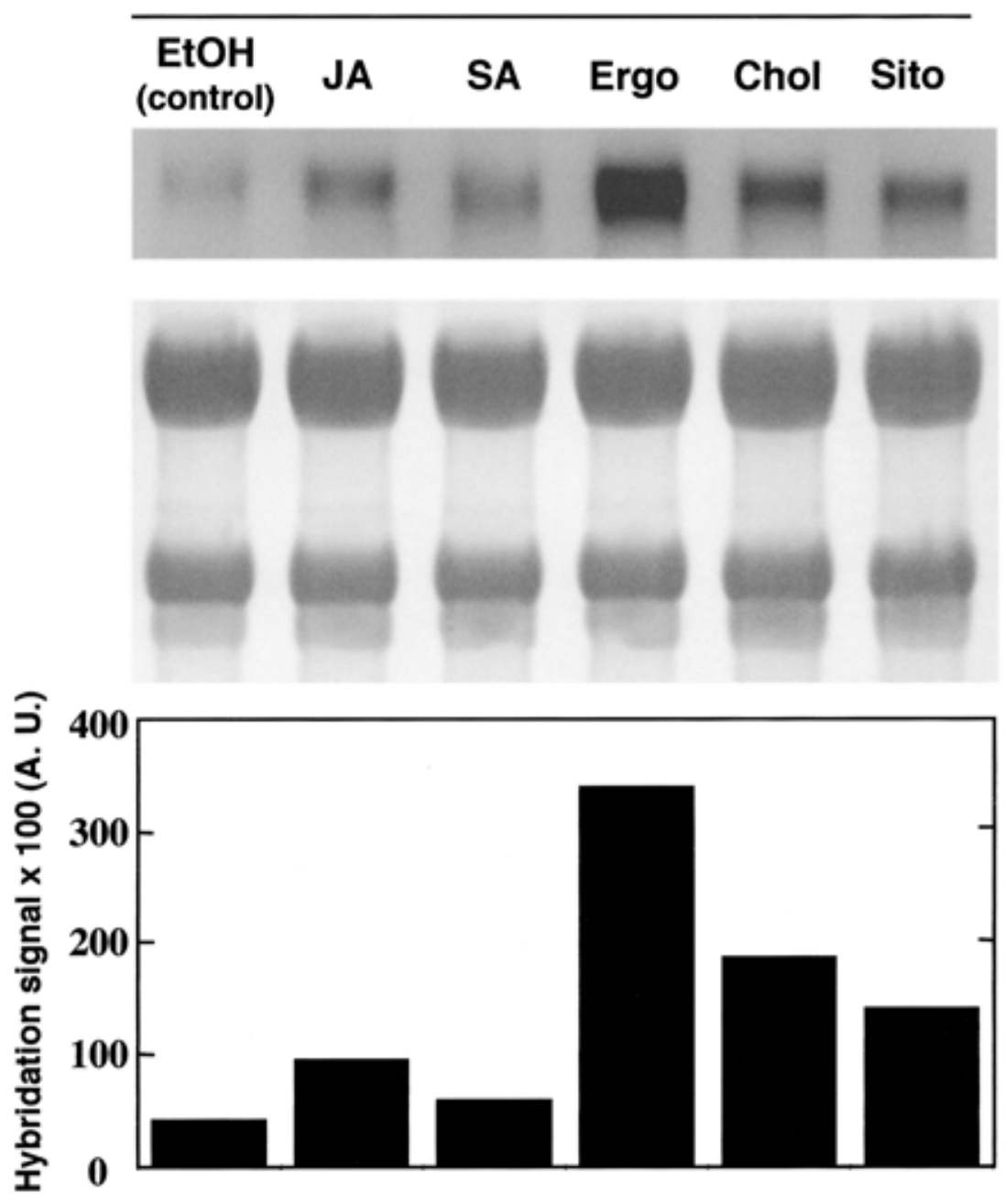

B
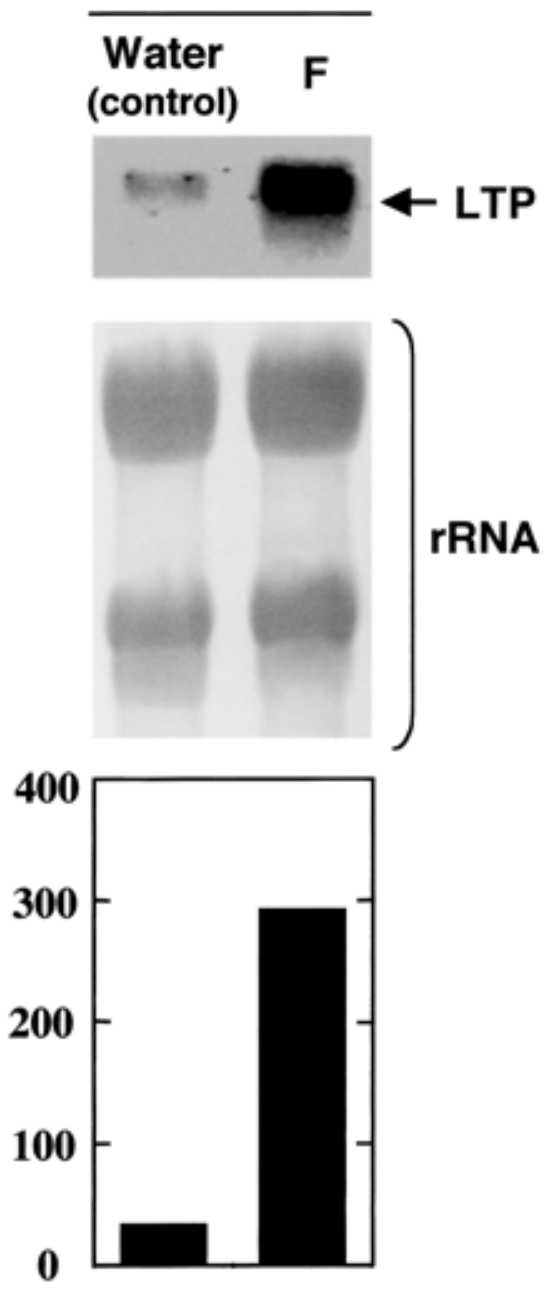

Fig. 2. Northern blot analysis of nonspecific lipid transfer proteins (nsLTPs) expression in 41B cell suspension cultures. RNAs were isolated from cells cultured in presence of $5 \mu \mathrm{M}$ of NOA ( $\beta$-naphtoxyacetic acid). A, JA: jasmonic acid (5 $\mu \mathrm{M})$; SA: salicylic acid $(5 \mu \mathrm{M})$; Ergo: ergosterol $(5 \mu \mathrm{M})$; Chol: cholesterol $(5 \mu \mathrm{M})$; Sito: sitosterol $(5 \mu \mathrm{M})$, dissolved in ethanol. A control was performed using the same amount of ethanol (EtOH lane). B, F: waterdialyzed Botrytis cinerea culture filtrate. A control was performed using the same amount of water (W lane). Upper panels: hybridization with full-length 41B-LTP cDNA probe; middle panels: methylene blue staining of rRNAs as a control for equal lane loading; lower panel: hybridization signal quantification. 
periment (Fig. 3). This visual estimation was confirmed by Phosphor-Imager quantification of the Northern blot membrane signals. The quantification was achieved by subtracting from the values obtained for the elicitor-treated cells, for each time point, the value obtained in the untreated control kinetics. At $30 \mathrm{~h}$ after induction, a 150-fold and 190-fold increase in hybridization signal was observed for ergosterol and Botrytis spp. elicitor treatment, respectively, compared with control cells. This reflects a strong and linear induction of mRNA accumulation with time in both cases, albeit a little more delayed in Botrytis spp. elicitor-treated cells.

\section{Isoform expression specificity.}

LTPs are encoded by multigenic families (Arondel et al. 2000; Coutos-Thévenot et al. 1993); therefore, there was a high probability that the probe used for Northern blot would not discriminate between different isoforms. The $3^{\prime}$ regions of the grape LTPs cDNAs are identical (Fig. 1), making it very difficult to design specific probes for each isoform. Furthermore, the transcript level is not always strictly related to the protein amount, due to translational control. To circumvent these limi- tations, cation-exchange high performance liquid chromatography (HPLC) analysis was used to investigate the diversity of isoform expression (Fig. 4). In the control, grape cells secreted only the P3 isoform, and lacked P2 and P1. However, a small amount of P4 was detected (just above the detection threshold). Such an expression pattern, particularly the positive response of the P3 isoform in control conditions, is new, because all results in the literature indicate that LTP genes are negatively regulated by auxin in suspension cells (Coutos-Thévenot et al. 1993; Song et al. 1998). The expression pattern in ergosteroltreated cells was different. P1, P2, and P4 isoforms were induced by ergosterol, whereas P3 was barely detectable. P2 was the major protein secreted by ergosterol-elicited cells. This pattern was qualitatively similar to the one already published for auxin-starved cells (Coutos-Thévenot et al. 1993), although there were differences in the relative level of each isoform expression. The proteins detected in each of the four HPLC fractions (P1, 2, 3, and 4) were assessed as nsLTP by sodium dodecyl sulfate (SDS)-polyacrylamide gel electrophoresis followed by Western blot analysis. Each fraction displayed a single, 9$\mathrm{kDa}$ band which cross-reacted with a polyclonal antibody

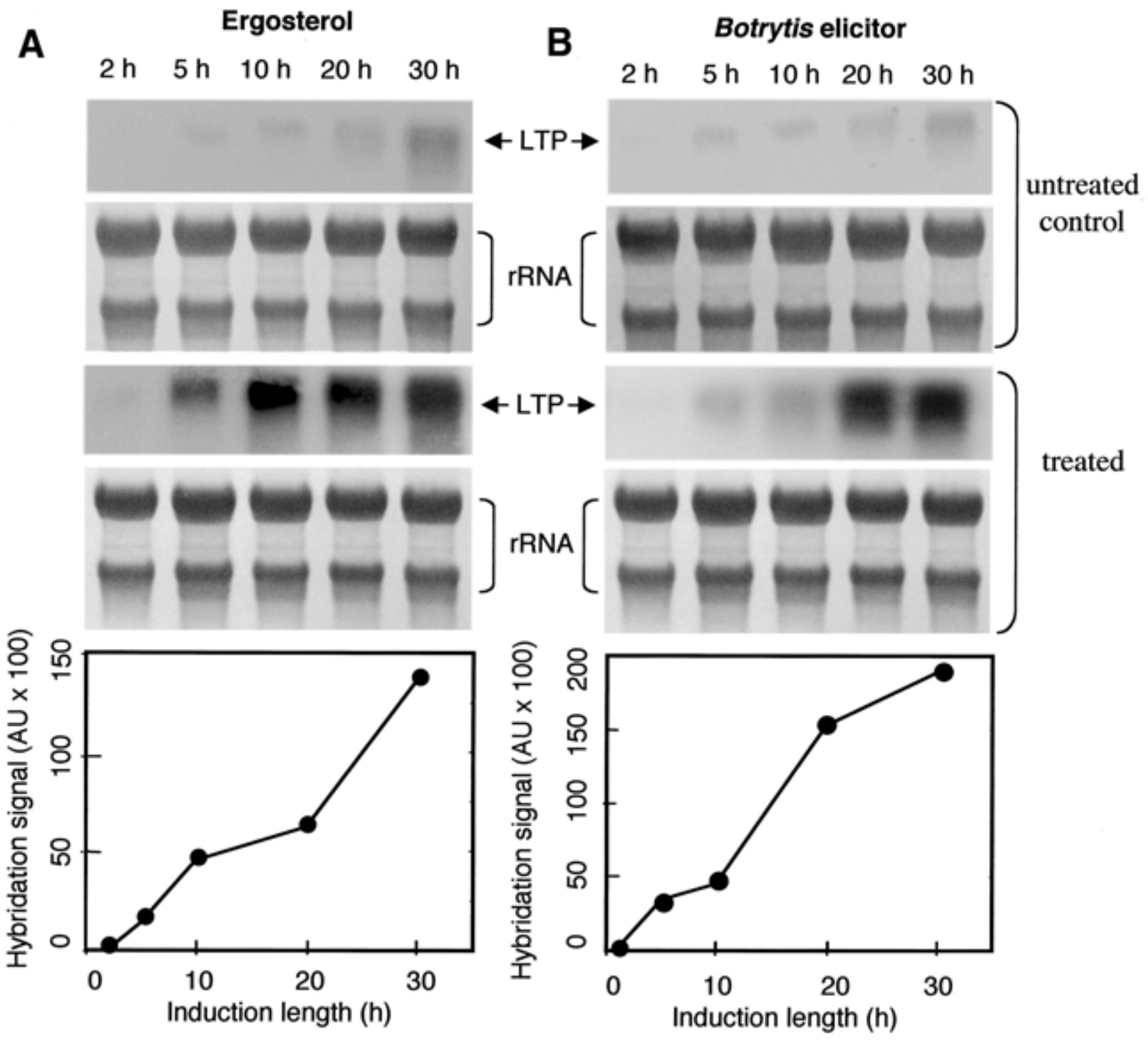

Fig. 3. Time-course analysis of nonspecific lipid transfer protein (nsLTP) mRNA accumulation in ergosterol or Botrytis spp. elicitor-treated cells. Cells were treated with $\mathbf{A}, 5 \mu \mathrm{M}$ of ergosterol or $\mathbf{B}, 0,085 \mu \mathrm{g} \mathrm{ml} \mathrm{m}^{-1}$ of the proteinaceous Botrytis spp. elicitor, in the presence of $5 \mu \mathrm{M}$ of NOA. Upper panels show hybridization signals and methylene blue staining of rRNAs, for both treated and untreated (control) kinetics. Lower panels show quantification of the hybridization signals with the Phosphor Imager. Hybridization signals are normalized by subtracting to each time point the hybridization value obtained at time zero. 
raised against a Maize nsLTP (data not shown). Antibody was a generous gift of J.-C. Kader (Université Pierre et Marie Curie, Paris).

\section{Fungitoxicity of LTPs.}

$B$. cinerea is the major fungal pathogen for grape. With regard to the numerous results involving LTPs as antifungal proteins (Cammue et al. 1995; Carvalho et al. 2001; Kristensen et al. 2000; Molina et al. 1993; Wijaya et al. 2000), the activity of the different isoforms was checked on $B$. cinerea conidia germination and mycelium growth. Compared with an untreated control, addition of different LTP concentrations affected neither germination of conidia in $100 \mathrm{mM}$ glucose solution supplemented with $1 \mathrm{mM} \mathrm{CaCl}_{2}$ (Fig. 5A) nor mycelium growth. Moreover, the morphology of hyphae was not altered (Fig. 5C). LTPs are small, highly basic proteins (isoelectric point around 10); therefore, two control treatments were done. Bovine serum albumin (BSA) was used as a negative control, and histones, which present the same physicochemical properties as LTPs (i.e., a highly basic isoelectric point) were used as a positive control. The same results were obtained with these two treatments: neither BSA nor histones affected conidia germination and mycelium growth (Fig. 5B).

When the same assay was performed in the absence of calcium, BSA did not affect germination of conidia. P1, P2, and P3 (F1 fraction) isoforms had no effect for concentrations up to $30 \mu \mathrm{g} \mathrm{ml}^{-1}$ and induced a slight decrease (10\%) of conidia ger- mination for higher concentrations. The germination rate was markedly decreased in the presence of P4 isoform (approximately $50 \%$ less germination at the highest concentration) and totally blocked with histones at concentration as low as $15 \mu \mathrm{g}$ $\mathrm{ml}^{-1}$ (Fig. 5D). In addition, mycelium growth was markedly reduced by the P4 isoform of LTP (Fig. 5F) and no growth was observed with histones (Fig. 5E).

\section{DISCUSSION}

The nsLTPs were originally described as proteins that have the ability to transfer lipid between membranes in vitro. This suggested a role for these proteins in intracellular lipid trafficking. The extensively described extracellular localization of the LTP (Coutos-Thévenot et al. 1992a, 1993; Kader 1997; Sterk et al. 1991; Thoma et al. 1993, 1994) has ruled out such a function in vivo. This raises the question of the in vivo role of LTPs.

Based on results published on onion (Cammue et al. 1995), sunflower (Regente and De la Canal 2000), cowpea (Carvalho et al. 2001), and sugar beet (Kristensen et al. 2000), a role was proposed for LTPs in plant defense mechanisms. In particular, Cammue and associates (1995) tested the inhibition of fungal growth by an LTP-like protein, (Ace-AMP1) that does not exhibit any lipid transfer activity, and three true nsLTPs (RsnsLTP, Ta-nsLTP, and Zm-nsLTP). Twelve different fungi species, including B. cinerea, were tested. Ace-AMP1 was shown

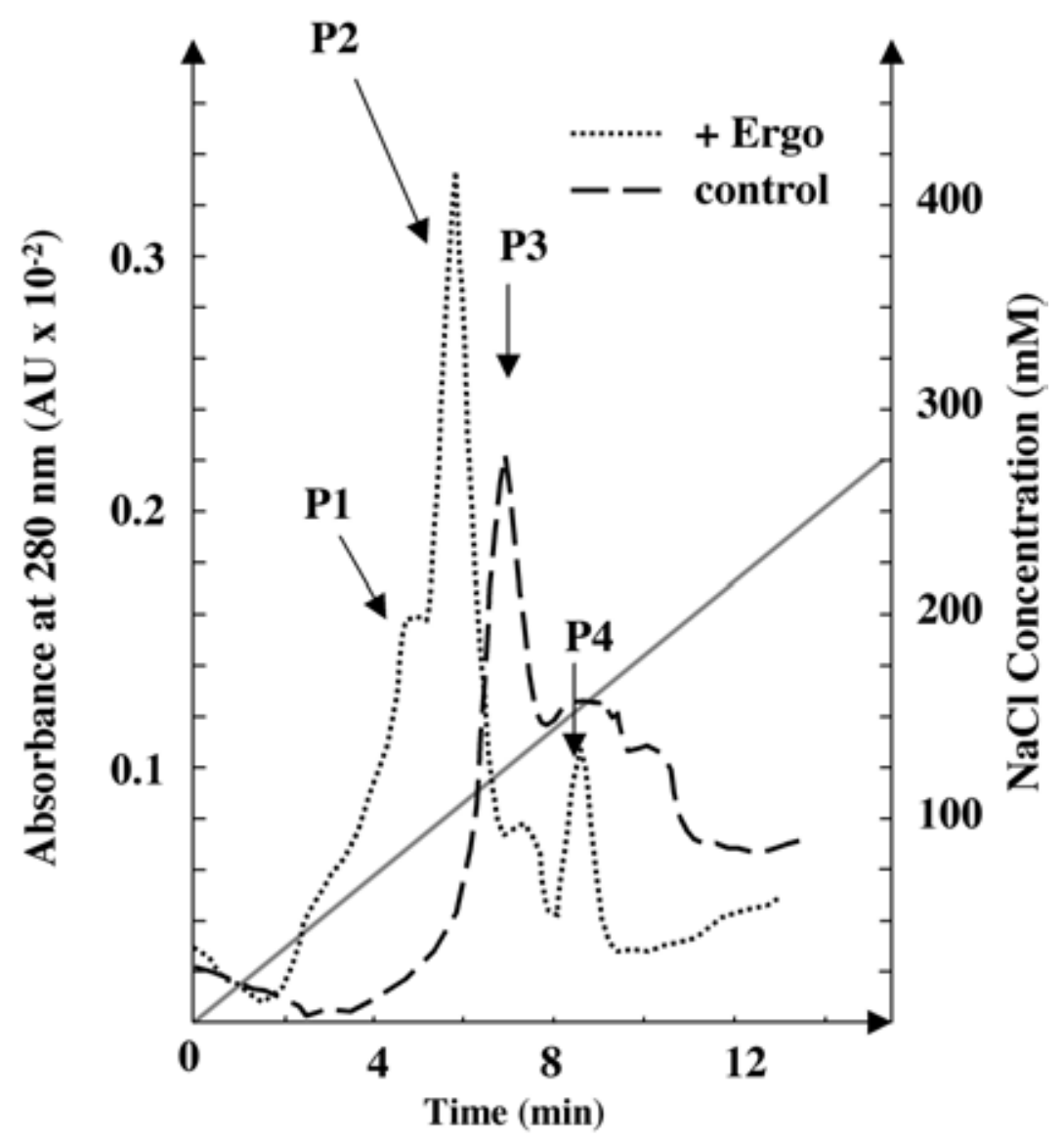

Fig. 4. Nonspecific lipid transfer protein (nsLTP) isoforms expression analysis in $41 \mathrm{~B}$ cells. Isoform expression patterns were analyzed by ion-exchange high-pressure chromatography (HPLC) in various conditions. Cell (packed cell volume, $1 \mathrm{ml}$ ) was inoculated in $250 \mathrm{ml}$ of glycerol-maltose medium supplemented with $5 \mu \mathrm{M}$ NOA. Extracellular proteins were extracted as described after treatment (10 days) by ergosterol (5 $\mu \mathrm{M})$ dissolved in ethanol (+ Ergo), and compared with the protein secreted in the control supplemented with an equivalent amount of ethanol (Control). After a 200-fold concentration, the total extract was loaded onto the column. Proteins were eluted by a linear gradient of $\mathrm{NaCl}$ as shown on the chromatogram. Elution was monitored by following absorbance at $280 \mathrm{~nm}$. Proteins are named P1 to P4 according to their elution order from the column, as previously described (Coutos-Thévenot et al. 1993). 
to be the most inhibitory. In addition, it was quite clear that the antifungal activity of Rs-nsLTP, Ta-nsLTP, and Zm-nsLTP strongly depended on the ionic strength of the assay medium. Indeed, addition of $1 \mathrm{mM} \mathrm{Ca}^{2+}\left(\mathrm{SMF}^{+}\right.$assay medium) almost abolished the antifungal effect. Even for the ns-LTP-like AceAPM1 protein, the presence of $1 \mathrm{mM}$ calcium markedly decreased the $50 \%$ inhibitory concentration $\left(\mathrm{IC}_{50}\right) 2$ - to 10 -fold. This led to the classification of LTPs in the pathogenesis-related proteins family (PR-14) (Van Loon and Van Strien 1999). The effects of calcium and ionic strength on LTP antifungal activity are surprising. Recent results indicate that some nsLTPlike proteins (CaMBP-10) may have calmodulin-binding properties (Liu et al. 2001). The experiments with the histone controls performed here (Fig. 5E) provide new insight. Histones, which are not antifungal protein but share with LTPs their small size and their high isoelectric point, are strongly antifungic (Fig. 5). This suggests that the effects of histones and grape LTPs on fungal growth is rather nonspecific and due to their physicochemical properties, which may affect, for example, the integrity of the fungus plasma membrane. A comparison of the isoelectric points of 10 LTPs from different species (including the grape P1) with 10 histones (based on sequences extracted from GenBank and calculation by the "PI/MW" software from Swiss-Prot) was made. This analysis gave values ranging from 9.02 to 9.5 and from 10.3 to 11.4 for nsLTP and histones, respectively. The most basic proteins (histones) were the most potent for fungal growth inhibition. None of the four LTP isoforms produced by $41 \mathrm{~B}$ cells has any effect on $B$. cinerea growth in the presence of calcium at a concentration very close to the physiological conditions (i.e., in the calcium-supplemented medium). It is well known that high calcium concentrations are found in the apoplast, where the fungus resides (Bush 1995). This supports the idea that grape nsLTPs probably are not antifungal protein in vivo.

Previous studies at the protein level showed that, in grape suspension cells, nsLTPs are induced by a somatic embryogenesisrelated signal: auxin starvation (Coutos-Thévenot et al. 1993; Sterk et al. 1991). The present data, obtained by Northern blot and HPLC analysis (Figs. 2, 3, and 4), indicate that nsLTPs also are induced by defense-related signals such as ergosterol, a proteinaceous elicitor secreted by B. cinerea and, to a lesser extent, JA. The fact that this increase in protein level is accompanied by an increase of LTP transcripts suggests a transcriptional control. HPLC analysis further distinguished between different isoforms, and showed that the P2 isoform is the major LTP produced in response to the ergosterol treatment. This differs from the induction of LTPs by auxin starvation, in which the most-produced isoform is P1 (Coutos-Thévenot et al. 1993). This means that, although LTPs are expressed in both situations (somatic embryogenesis and defense response), the isoform expression patterns are different, suggesting that the response of LTP genes to auxin and elicitor signals is different. The kinetics of transcript accumulation indicate that the response of LTP genes to elicitor treatment occurs quite fast, the mRNA level starting to increase $5 \mathrm{~h}$ after the treatment by ergosterol or by the elicitor from Botrytis spp. This kind of time course also has been observed for other PR proteins in grape, such as chitinase, $\beta$-1,3-glucanases, or class 10 pathogenesis-related (PR) proteins (Derckel et al. 1998; Robert et al. 2001). All these results concur with the conclusion that at least some grape LTP isoforms (i.e., P2 and P4) can be described as defense-related proteins, and may play a role in plant defense mechanisms, even if this is not a direct role as antibiotic compounds. These results are in agreement with the classification of plant LTPs in the PR proteins by Van Loon and Van Strien (1999).

However, the precise function of LTPs in plant defense mechanisms is still unclear. An important point is the function, within the context of plant defense response, of proteins excreted in the extracellular compartment and able to bind hydrophobic (Meijer et al. 1993) and amphiphilic molecules (Pato et al. 2001). Another class of cystein-rich proteins, named elicitins, which are secreted by oomycete fungi such as Phytophtora cryptogea, also are able to bind lipid molecules and various sterols, including the fungal-specific ergosterol (Mikès et al. 1998; Vauthrin et al. 1999). Moreover, the interaction of the elicitin-sterol complex with a plant plasma-membrane receptor triggers the elicitation of defense mechanisms in tobacco (Osman et al. 2001). No plant elicitin homolog is known so far. Nevertheless, even though little homology can be found between the primary sequences of nsLTPs and elicitins, their three-dimensional structures present significant analogies (Blein et al. 2002). A similar signaling role for an LTP-ergosterol complex during plant-fungus interaction constitutes an appealing hypothesis, but the existence of such a complex has never been shown. Indeed, according to literature, the rigid backbone of sterol molecules seems to prevent their binding to nsLTPs (Blein et al. 2002; Pato et al. 2001). The other potential ligands that may play a role in the LTP signaling pathway still need to identified.

Recently, new and decisive results emerged in the literature. It has been demonstrated that nsLTPs bind to specific sites on plasma membrane vesicles from tobacco. Moreover, nsLTP and elicitins appear to compete for the same binding sites (Buhot et al. 2001). It is, therefore, tempting to think that receptors for nsLTPs exist at the plant cell surface, and that these are identical to the elicitins' own binding sites. In addition, a T-DNA tagged Arabidopsis LTP mutant (dir 1-1) recently was shown to be affected in the systemic acquired resistance (SAR) signaling pathway (Maldonado et al. 2002). According to these authors, the DIR 1 gene product could be the SAR mobile signal or may transport the SAR signal to the phloem for export to distant tissue. Future work will focus on this line of research.

\section{MATERIAL AND METHODS}

\section{Elicitation of grape cell suspension cultures.}

Grape cells (embryogenic line derived from the 41B rootstock Vitis vinifera $\times V$. berlandieri hybrid, supplied by Moëtet-Chandon, Epernay, France) were established in the presence of $5 \mu \mathrm{M}$ NOA ( $\beta$-naphtoxyacetic acid) at $21^{\circ} \mathrm{C}$ in the dark on glycerol-maltose medium ( $\mathrm{pH} 5.8$ ) (Coutos-Thevenot et al. 1992b) and subcultured weekly under orbital shaking (100 $\mathrm{rpm})$. Specific elicitation treatments are indicated in the figure legends. JA, SA, and sterols were purchased from Sigma and were at the highest purity available. All chemicals were dissolved in ethanol.

\section{RNA extraction and Northern blot analysis.}

Total RNAs were extracted from 18-day-old cell cultures using the Perfect RNA Eukaryotic mini kit (Eppendorf, Barkhausenweg, Germany) according to the manufacturer's instructions. Total RNA $(20 \mu \mathrm{g})$ was mixed with loading buffer (32.7\% formamide, $1.21 \mathrm{M}$ formaldehyde) and loaded onto a $1.2 \%$ agarose gel made with MEN buffer (20 mM MOPS pH 7.0, $5 \mathrm{mM}$ sodium acetate, $1 \mathrm{mM}$ EDTA) and supplemented with $2.25 \mathrm{M}$ formaldehyde. The gels were run for $5 \mathrm{~h}$ at $50 \mathrm{~V}$ in MEN buffer, and capillary blotted onto a Hybond $\mathrm{N}$ nylon membrane (Amersham Pharmacia Biotech, Piscataway, NJ, U.S.A.) with $10 \times \mathrm{SSC}$ buffer $(1 \times \mathrm{SSC}$ is $0.15 \mathrm{M} \mathrm{NaCl}$ plus $0.015 \mathrm{M}$ sodium citrate). RNAs were cross linked to the membrane by heating for $2 \mathrm{~h}$ at $80^{\circ} \mathrm{C}$. At this stage, the membrane was stained with methylene blue to check for equal RNA loading on the gel. Hybridization was performed overnight at $65^{\circ} \mathrm{C}$ in a buffer containing $0.25 \mathrm{M}$ sodium phosphate $(\mathrm{pH} 7.2), 1 \%$ 
With $\mathrm{Ca}^{2+}$

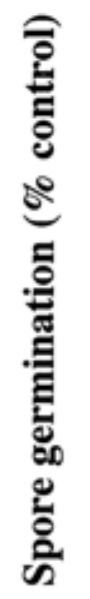

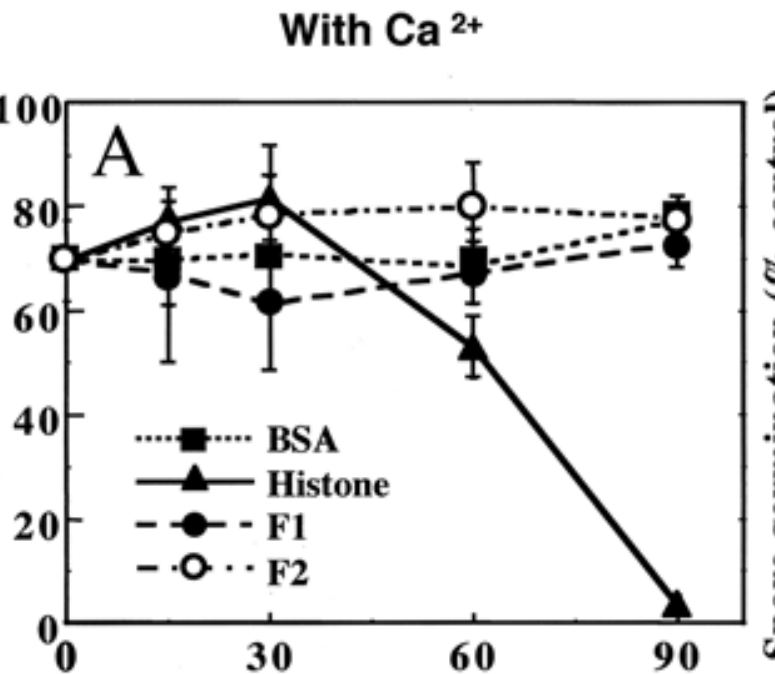

Protein concentration $\left(\mu \mathrm{g} \cdot \mathrm{ml}^{-1}\right)$
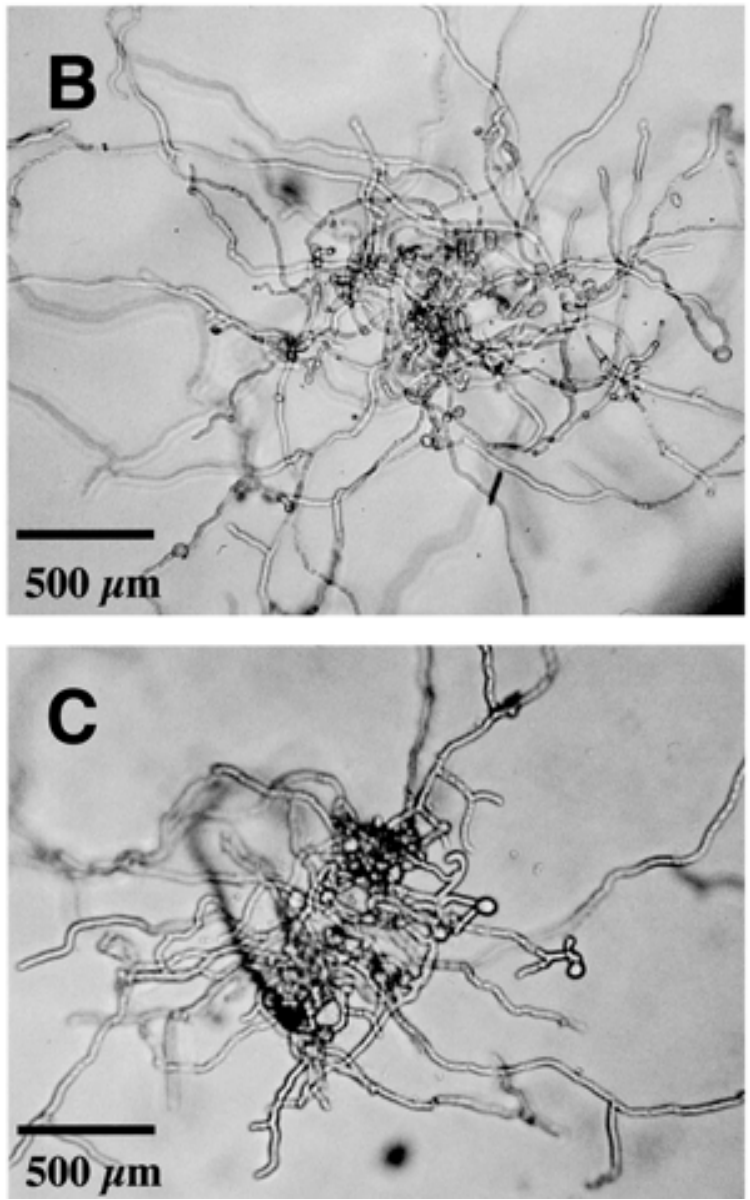

Without $\mathrm{Ca}^{2+}$
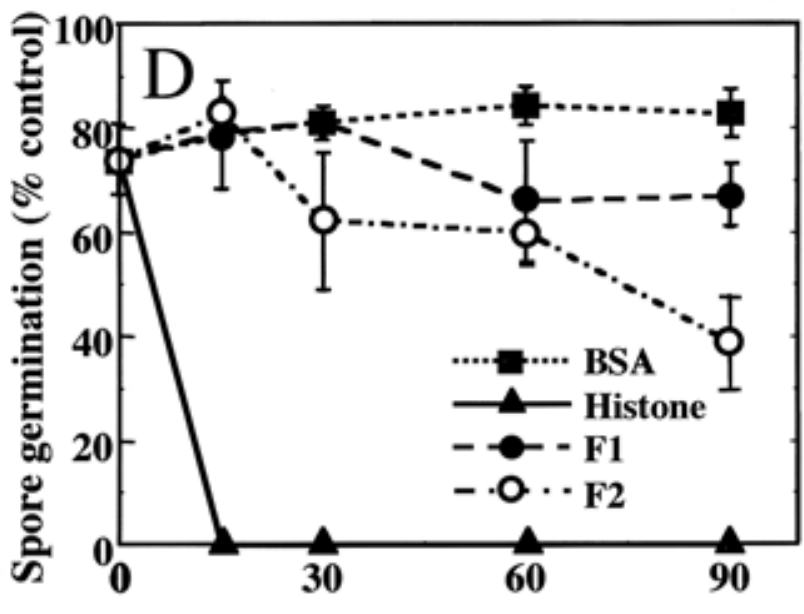

Protein concentration $\left(\mu \mathrm{g} \cdot \mathrm{ml}^{-1}\right)$
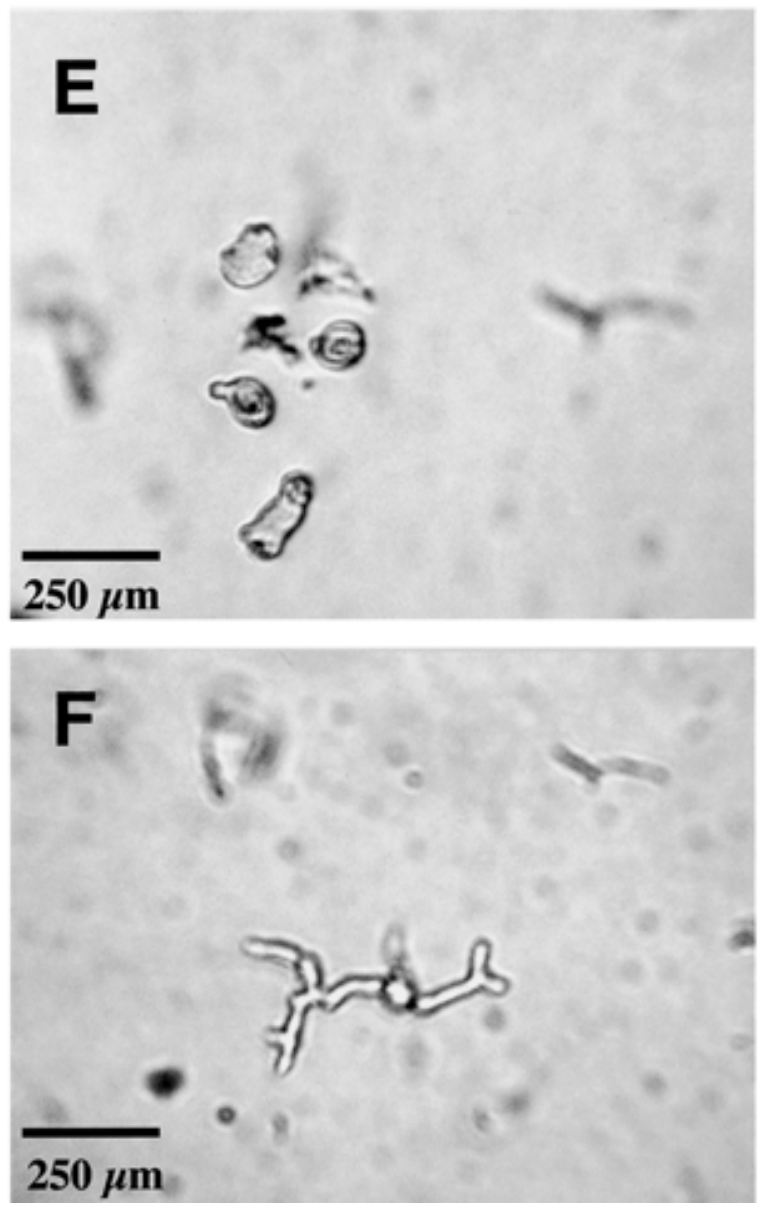

Fig. 5. Antifungal activity trials of grapevine nonspecific lipid transfer proteins (nsLTPs) compared with bovine serum albumin (BSA) and histone controls. Conidia germination and mycelium growth were monitored $96 \mathrm{~h}$ after inoculation for four concentrations of protein $\left(15,30,60\right.$, and $\left.60 \mu \mathrm{g} \mathrm{ml} \mathrm{H}^{-1}\right)$ The number of germinated conidia were counted in two independent experiments with three replicates. The percentage of germination was calculated as the number of germinated conidia compared with the total number of conidia in each well. The test was performed in $100 \mathrm{mM}$ glucose, in the presence of $1 \mathrm{mM} \mathrm{CaCl}$ (with $\mathrm{Ca}^{2+}$ ) or in absence of calcium (without $\mathrm{Ca}^{2+}$ ). Each well was pictured after $96 \mathrm{~h}$ to visualize mycelium growth. Conidia were considered germinated when a mycelium filament was emitted. A, Spore germination in the presence of $\mathrm{Ca}^{2+} ; \mathbf{B}$ and $\mathbf{C}$, pictures of germinated conidia in the presence of $\mathrm{Ca}^{2+}$ and BSA or F1 LTP fraction (mix of P1, P2, and P3) at $30 \mu \mathrm{g} \mathrm{ml}^{-1}$, respectively. Magnification $\times 100$. D, Spore germination in the absence of $\mathrm{Ca}^{2+}$. E and $\mathbf{F}$, Pictures of conidia in the absence of $\mathrm{Ca}^{2+}$ and histones or F2 LTP fraction (pure P4) at $30 \mu \mathrm{g} \mathrm{ml}{ }^{-1}$, respectively. Magnification $\times 200$. 
BSA, 7\% SDS, and $1 \mathrm{mM}$ EDTA. Radiolabeled DNA probes were synthesized by random priming, using the ready-to-go DNA labeling beads kit (Amersham Pharmacia Biotech) and $\left[{ }^{32} \mathrm{P}\right]$-dCTP (Amersham Pharmacia Biotech). After hybridization, the membranes were washed at $65^{\circ} \mathrm{C}$ twice in $2 \times$ $\mathrm{SSC} / 0.1 \% \mathrm{SDS}$, twice in $0.5 \times \mathrm{SSC} / 0.1 \% \mathrm{SDS}$, and once in $0.2 \times \mathrm{SSC} / 0.1 \%$ SDS. Membranes finally were exposed to hyperfilms MP (Amersham Pharmacia Biotech) at $-80^{\circ} \mathrm{C}$ for autoradiography. Alternatively, membranes were exposed for $24 \mathrm{~h}$ to phosphoscreens for quantification with a Storm Phosphor Imager (Molecular Dynamics, Sunnyvale, CA, U.S.A.).

\section{RT-PCR and RACE-PCR}

The mRNA were purified from total RNA (prepared as described above) using oligo-dT cellulose type 7 spin columns (Amersham Pharmacia Biotech). First-strand and doublestrand cDNA synthesis was performed using the Marathon cDNA amplification kit (Clontech, Palo Alto, CA, U.S.A.), according to the manufacturer's instructions.

PCR using the degenerated primers (sequences described above) were performed onto a PCR Express thermocycler (Hybaid Instruments, Holbrook, NY, U.S.A.) according to the following temperature program: $95^{\circ} \mathrm{C}, 5 \mathrm{~min}$ (initial denaturation step); then $95^{\circ} \mathrm{C}, 30 \mathrm{~s} ; 50^{\circ} \mathrm{C}, 45 \mathrm{~s}$ (primer annealing), and $72^{\circ} \mathrm{C}, 2 \mathrm{~min}$ (primer extension) for a total of 30 cycles.

RACE-PCR was performed with the Marathon cDNA amplification kit (Clontech), using the following gene-specific nondegenerated primers: 5'RACE primer 5'-TTGCAAGGCCGAGATTGATG and 3'RACE primer 5'-GGATTAAGAATCTCAACAGCG). Thermal cycling was set as recommended by the manufacturer.

\section{Lipid transfer protein purification.}

Purification was performed using an HPLC system (Spectra Physics SP 8800 linked to a variable wavelength detector SP 700 and a Chromjet integrator) in a two-step method described previously (Coutos-Thévenot et al. 1993). Briefly, an 18-dayold culture medium was concentrated 200-fold using an Amicon ultrafiltration system (Amicon WR Grace and Co., Beverly, MA, U.S.A.) equipped with a YM3 membrane (cut off, 3 $\mathrm{kDa}$ ). The concentrate was loaded onto a cation exchange column (Selfpack POROS 20CM, 8.5 by $0.8 \mathrm{~cm}$; Applied Biosystems, Foster City, CA, U.S.A.) previously equilibrated with 25 $\mathrm{mM}$ sodium phosphate buffer ( $\mathrm{pH}$ 6.5). The bound proteins were eluted by a linear $\mathrm{NaCl}$ gradient ( 0 to $275 \mathrm{mM}$ in 15 $\mathrm{min})$. The collected fractions were further purified on a hydrophobic interaction column (Applied Biosystem Selfpack POROS HP2, 13.5 by $0.8 \mathrm{~cm}$ ) equilibrated with a buffer containing $50 \mathrm{mM}$ sodium phosphate and $1.8 \mathrm{M}$ ammonium sulfate $(\mathrm{pH} 7.0)$. Bound proteins were eluted by a linear ammonium sulfate gradient (1.8 $\mathrm{M}$ to $0 \mathrm{M}$ in $20 \mathrm{~min}$ ). Protein elution was monitored at $280 \mathrm{~nm}$.

\section{Preparation of the elicitor fraction from $B$. cinerea.}

B. cinerea (Botryotinia fucheliana p.f.) strain T4 (kind gift of Y. Brygoo, INRA Versailles) was multiplied in a $9.5-\mathrm{cm}$ petri dish with $15 \mathrm{ml}$ of half-strength V8 medium supplemented with $\mathrm{KH}_{2} \mathrm{PO}_{4}$ at $5 \mathrm{~g} \mathrm{liter}^{-1}$ and bacto agar (pH 6.0) at $30 \mathrm{~g} \mathrm{liter}^{-1}$ and subcultured every month. For elicitor production, Roux flasks containing $250 \mathrm{ml}$ of Nitsch-Nitsch medium, pH 6.0 (Nitsch and Nitsch 1969) were inoculated with 2,000 conidia of the T4 strain and cultured for 14 days at $25^{\circ} \mathrm{C}$ with a photoperiod of $16 \mathrm{~h}$ light, $8 \mathrm{~h}$ dark. The crude elicitor preparation obtained from 4 liters of culture filtrate was first concentrated by dialysis (10,000-molecular weight [MW] cutoff) against polyethylene glycol (15,000 to $20,000 \mathrm{MW})$. The concentrate then was sterilized in a $0.2-\mu \mathrm{m}$ filter (Sterivex, Milli- pore, Bedford, MA, U.S.A.). The 15-ml concentrated fraction was diluted to $50 \mathrm{ml}$ with anion equilibration buffer $(20 \mathrm{mM}$ ethanolamine, $\mathrm{pH}$ 10.8) and loaded onto the column (Hi-trap Mono Q, $5 \mathrm{ml}$, Amersham Pharmacia Biotech) through a superloop injector using an AKTA purifier system. The column was washed with $10 \mathrm{ml}$ of the equilibration buffer and the adsorbed proteins were eluted with a linear $\mathrm{NaCl}$ gradient ( 0 to $700 \mathrm{mM}$ in equilibration buffer). The flow rate was $5 \mathrm{ml} \mathrm{min} \mathrm{m}^{-1}$ with a total volume of $150 \mathrm{ml}$. The purification of the elicitor was monitored by measuring the ability of the fractions to induce $\mathrm{H}_{2} \mathrm{O}_{2}$ production in grape cell suspensions. In all, $20 \mu \mathrm{l}$ of each fraction was applied on 1-ml aliquots of grape cell suspension and $\mathrm{H}_{2} \mathrm{O}_{2}$ production was determined 20 min after treatment. Active fractions were pooled and concentrated by ultrafiltration (Macrosep $10 \mathrm{~K}$, Pall, Zaventem, Belgium). Part of the concentrated fraction $(0.5 \mathrm{ml})$ was further purified by size exclusion chromatography on a Superdex 75 HR/6/30 column (Amersham Pharmacia Biotech). The elution buffer $(0.05$ $\mathrm{M} \mathrm{NaH} \mathrm{PO}_{4}, 0.05 \mathrm{M} \mathrm{Na}_{2} \mathrm{HPO}_{4}, 0.15 \mathrm{M} \mathrm{NaCl}, \mathrm{pH}$ 7.0) was eluted at $0.5 \mathrm{ml} \mathrm{min} \mathrm{m}^{-1}$. Active fractions were dialyzed against water and pooled $(500 \mu \mathrm{l})$ before use.

\section{Antifungal assays.}

The Botrytis cinerea strain was obtained from B. Dubos (INRA, Bordeaux France) and subcultured each month on malt-agar culture medium (malt extract at $15 \mathrm{~g} \mathrm{liter}^{-1}$, bacto agar at $20 \mathrm{~g} \mathrm{liter}^{-1}$ ) in the dark at $21^{\circ} \mathrm{C}$. Conidia were obtained by fungus inoculation on V8 (commercial Campbell's vegetable juice) culture medium diluted to half and supplemented with bacto agar at $20 \mathrm{~g} \mathrm{liter}^{-1}$ under light at $21^{\circ} \mathrm{C}$. Antifungal activity of LTPs was tested both on germination and mycelium growth in 24-well culture boxes (Nunc, Roskilde, Denmark). Conidia (50 per well) were inoculated in $1 \mathrm{ml}$ of liquid 100 $\mathrm{mM}$ glucose solution, supplemented or not with $1 \mathrm{mM} \mathrm{CaCl}_{2}$, at four protein concentrations $\left(15,30,60\right.$, and $\left.90 \mu \mathrm{g} \mathrm{ml}^{-1}\right)$. Controls were made using water, BSA, or histones (Sigma, Saint Quentin, France), the latter having an isoelectric point close to that of basic nsLTPs. Conidia in germination were counted under an inverted microscope at different times, and mycelium growth was estimated by the length of the filaments.

\section{Sequence analysis.}

For each cDNA, products from two independent PCR reactions were sequenced (Eurogentec, Ivoz-Ramet, Belgium) in both directions. Sequence alignments were performed by the Clustal method, using the Megalign program of the DNA Star package.

\section{ACKNOWLEDGMENTS}

This work was supported by grants from CNRS (Centre National de la Recherche Scientifique), RVVS (Réseau Vigne et Vin Septentrionaux), LVMH (Louis Vuitton Moët Henessy), and the Conseil Régional PoitouCharentes.

\section{LITERATURE CITED}

Arondel, V., Vergnolle, C., Cantrel, C., and Kader, J.-C. 2000. Lipid transfer proteins are encoded by a small multigene family in Arabidopsis thaliana. Plant Sci. 157:1-12.

Blein, J.-P., Coutos-Thevenot, P., Marion, D., and Ponchet, M. 2002. Plant signaling mediated by lipid binding protein. 2002. Trends Plant Sci. 7:293-296

Blilou, I., Ocampo, J. A., and Garcia-Garrido, J. M. 2000. Induction of Ltp (lipid transfer protein) and Pal (phenylalanine ammonia-lyase) gene expression in rice roots colonized by the arbuscular mycorrhizal fungus Glomus mosseae. J. Exp. Bot. 51:1969-1977.

Buhot, N., Douliez, J.-P., Jacqmard, A., Marion, D., Tran, V., Maume, B. F., Milat, M.-L., Ponchet, M., Mikès, V., Kader, J.-C., and Blein, J.-P. 
2001. A lipid transfer protein binds to a receptor involved in the control of plant defense responses. FEBS (Fed. Eur. Biochem. Soc.) Lett. 509:27-30.

Bush, D. S. 1995. Calcium regulation in plant cells and its role in signaling. Annu. Rev. Plant Physiol. Plant Mol. Biol. 46:95-122.

Cammue, B. P. A., Thevissen, K., Hendricks, M., Eggermont, K., Goderis, I. J., Proost, P., Van Damme, J., Osborn, R. W., Guerbette, F., Kader, J.-C., and Broekaert, W. F. 1995. A potent antimicrobial protein from onion seeds showing sequence homology to plant lipid transfer proteins. Plant Physiol. 109:445-455.

Carvalho, A. O., Machado, O. L. T., Cunha, M. A., Santos, I. S., and Gomes, V. M. 2001. Antimicrobial peptides and immunolocalization of a LTP in Vigna unguiculata seeds. Plant Physiol. Biochem. 39:137146.

Coutos-Thevenot, P., Goebel-tourant, I., Mauro, M. C., Jouanneau, J.-P., Boulay, M., Deloire, A., and Guern, J. 1992b. Somatic embryogenesis from grapevine cells. I-Improvement of embryo development by changes in culture conditions. Plant Cell Tissue Organ Cult. 29:125-133.

Coutos-Thévenot, P., Jouenne, T., Maës, O., Guerbette, F., Grosbois, M. Le Caer, J. P., Boulay, M., Deloire, A., Kader, J. C., and Guern, J. 1993. Four 9-kDa Proteins excreted by somatic embryos of grapevine are isoforms of lipid-transfer proteins. Eur. J. Biochem. 217:885-889.

Coutos-Thévenot, P., Maës, O., Jouenne, T., Mauro, M. C., Boulay, M., Deloire, A., and Guern, J. 1992a. Extracellular protein patterns of grapevine cell suspensions in embryogenic and non-embryogenic situations. Plant Sci. 86:137-145.

Derckel, J. P., Audran, J. C., Haye, B., Lambert, B., and Legendre, L. 1998. Characterization, induction by wounding and salicylic acid, and activity against Botrytis cinerea of chitinases and $\beta$-1,3-glucanases of ripening grape berries. Physiol. Plant. 104:56-64.

Douady, D., Grosbois, M., Guerbette, F., and Kader, J.-C. 1985. Purification of phospholipid transfer protein from maize seeds using a twostep chromatographic procedure. Physiol. Veg. 23:373-380.

Fillion, L., Ageorges, A., Picaud, S., Coutos-Thévenot, P., Lemoine, R., Romieu, C., and Delrot, S. 1999. Cloning and expression of a hexose transporter gene expressed during the ripening of grape berry. Plant Physiol. 120:1083-1094.

Fleming, A. J., Mandel, T., Hofmann, S., Sterk, P., De Vries, S. C., and Kuhlemeier, C. 1992. Expression pattern of a putative lipid transfer protein gene within the shoot apex. Plant J. 2:855-862.

Granado, J., Georg, F., and Boller, T. 1995. Perception of fungal sterols in plants. Plant Physiol. 107:485-490.

Guerbette, F., Grosbois, M., Jolliot-Croquin, A., Kader, J. C., and Zachowski, A. 1999. Comparison of lipid binding and transfer properties of two lipid transfer proteins from plant. Biochemistry 38:1413114137.

Jégou, S., Douliez, J.-P., Mollé, D., Bolvin, P., and Marion, D. 2000. Purification and structural characterization of LTP1 polypeptides from beer. J. Agric. Food Chem. 48:5023-5029.

Kader, J.-C. 1975. Proteins and the intracellular exchange of lipids: stimulation of phospholipids exchange between mitochondria and microsomal fraction by protein isolated from potato tuber. Biochim. Biophys. Acta 380:31-44.

Kader, J.-C. 1996. Lipid transfer protein in plants. Annu. Rev. Plant Physiol. Plant Mol. 47:627-654.

Kader, J.-C. 1997. Lipid-transfer proteins: a puzzling family of plant proteins. Trends Plant Sci. 2:66-70.

Kader, J.-C., Julienne, M., and Vergnolle, C. 1984. Purification and characterization of a spinach-leaf protein capable of transferring phospholipid from liposomes to mitochondria or chloroplasts. Eur. J. Biochem. 139:411-416.

Kristensen, A. K., Brunstedt, J., Nielsen, K. K., and Mikkelsen, J. D. 2000. Characterization of a new antifungal non-specific lipid transfer protein (nsLTP) from sugar beet leaves. Plant Sci. 155:31-40.

Liu, H., Xue, L., Li, C., Zhang, R., and Ling, Q. 2001. Calmodulin-bind- ing protein $\mathrm{BP}-10$, a probable new member of plant nonspecific lipid transfer protein superfamily. Biochem. Biophys. Res. Commun. 285:633-638.

Maldonado, A. M., Doerner P., Dixon, R. A., Lamb, C. J., and Cameron, R. K. 2002. A putative lipid transfer protein involved in systemic resistance signaling in Arabidopsis. Nature 419:399-403.

Meijer, E. A., De Vries, S. C., Sterk, P., Gadella, D. W., Wirtz, K. W., and Hendricks, T. 1993. Characterization of a non-specific lipid transfer protein EP2 from carrot (Daucus carota L.). Mol. Cell Biochem. 123:159-166

Mikès, V., Milat, M.-L., Ponchet, M., Panabières, F., Ricci, P., and Blein, J.-P. 1998. Elicitins, proteinaceous elicitors of plant defenses, are a new class of sterol carrier proteins. Biochem. Biophys. Res. Commun. 245:133-139.

Molina, A., and Garcia-Olmedo, F. 1997. Enhanced tolerance to bacterial pathogens caused by the transgenic expression of barley lipid transfer protein LTP2. Plant J. 12:669-675.

Molina, A., Segura, A., and Garcia-Olmedo, F. 1993. Lipid transfer proteins (nsLTP) from barley and maize leaves are potent inhibitors of bacterial and fungal plant pathogens. FEBS (Fed. Eur. Biochem. Soc.) Lett. 316:119-122.

Nitsch, J. P., and Nitsch, C. 1969. Haploid plants from pollen grains. Science 169:85-90.

Osman, H., Vauthrin, S., Mikès, V., Milat, M.-L., Panabières, F., Marais, A., Brunie, S., Maume, B., Ponchet, M., and Blein, J.-P. 2001. Mediation of elicitin activity is assumed by elicitin-sterol complex. Mol Biol. Cell 12:2825-2834

Pato, C., Le Borgne, M., Le Baut, G., Le Pape, P., Marion, D., and Douliez, J.-P. 2001. Potential application of lipid transfer protein for drug delivery. Biochem. Pharmacol. 62:555-560.

Regente, M. C., and De la Canal, L. 2000. Purification, characterization and antifungal properties of a lipid-transfer protein from sunflower (Helianthus annuus) seeds. Physiol. Plant. 110:158-163.

Robert, N., Ferran, J., Breda, C., Couthos-Thévenot, P., Boulay, M., Buffard, D., and Esnault, R. 2001. Molecular characterization of the incompatible interaction of Vitis vinifera leaves with Pseudomonas syringae pv. pisi: expression of genes coding for stilbene synthase and class 10 PR-proteins. Eur. J. Plant Pathol. 107:249-261.

Song, J. Y., Choi, D. W., Lee, J. S., Kwon, Y. M., and Kim, S. G. 1998. Cortical tissue-specific accumulation of the root-specific ns-LTP transcripts in the bean (Phaseolus vulgaris) seedlings. Plant Mol. Biol. 38:735-742.

Sterk, P., Booij, H., Schellekens, G. A., Van Kammen, A., and De Vries, S. C. 1991. Cell-specific expression of the carrot EP2 lipid transfer protein gene. Plant Cell 3:907-921.

Thoma, S., Hecht, U., Kipper, A., Botella, J., De Vries, S. C., and Somerville, C. 1994. Tissue specific expression of a gene encoding a cell wall-localized lipid transfer protein from Arabidopsis. Plant Physiol. 105:35-45.

Thoma, S., Kanedo, Y., and Somerville, C. 1993. A non-specific lipid transfer protein from Arabidopsis is a cell wall protein. Plant J. 3:427436.

Van Loon, L. C., and Van Strien, E. A. 1999. The family of pathogenesisrelated proteins, their activities, and comparative analysis of PR1-type proteins. Physiol. Mol. Plant Pathol. 55:85-97.

Vauthrin, S., Mikès, V., Milat, M.-L., Ponchet, M., Maume, B., Osman, H., and Blein, J.-P. 1999. Elicitins trap and transfer sterols from micelles, liposomes and plant plasma membranes. Biochim. Biophys. Acta 1419:335-342.

Wijaya, R., Neumann, G. M., Condron, R., Hughes, A. B., and Polya, G. M. 2000. Defense proteins from seeds of Cassia fistula include a lipid transfer protein homologue and a protease inhibitory plant defensin. Plant Sci. 159:243-255.

Yamada, M. 1992. Lipid transfer protein in plant and microoganisms. Plant Cell Physiol. 33:1-6. 